\title{
Review of the use of phase change materials (PCMs) in buildings with reinforced concrete structures
}

\author{
O. Pons ${ }^{\mathrm{a}} \bowtie$, A. Aguado ${ }^{\mathrm{a}}$, A.I. Fernández ${ }^{\mathrm{b}}$, L.F. Cabeza ${ }^{\mathrm{c}}$, J.M. Chimenos ${ }^{\mathrm{b}}$ \\ a. Universitat Politécnica de Catalunya - UPC (Barcelona, Spain) \\ b. Universitat de Barcelona (Barcelona, Spain) \\ c. GREA Innovació Concurrent, Universitat de Lleida, (Lleida, Spain) \\ $\triangle$ oriol.pons@upc.edu
}

\begin{abstract}
Phase change materials are capable of storing and releasing energy in the form of heat in determined temperature ranges, so to increase a building's thermal inertia, stabilize its indoor temperatures and reduce its energetic demand. Therefore, if we used these materials we could have more energetically efficient buildings. Nevertheless, are these materials most appropriate to be used in buildings? Could the incorporation of phase change materials in buildings with concrete structures be generalized? This article aims to carry out a review of these phase change materials from construction professionals' points of view, study their applications for buildings with reinforced concrete structures and the key points for these applications, draw conclusions and provide recommendations useful for all professionals within the sector who are considering the application of these materials.
\end{abstract}

KEYWORDS: Phase Change Materials (PCM); Energy efficiency; Reinforced concrete; Structures

Citation / Citar como: Pons, O.; Aguado, A.; Fernández, A.I.; Cabeza, L.F.; Chimenos, J.M. (2014) Review of the use of phase change materials (PCMs) in buildings with reinforced concrete structures. Mater. Construcc. 64 [315], e031 http://dx.doi.org/10.3989/mc.2014.05613.

RESUMEN: Revisión crítica del uso de materiales de cambio de fase en edificios con estructuras de hormigón armado. Los materiales de cambio de fase son capaces de almacenar y liberar energía en forma de calor en un determinando rango de temperaturas, y así aumentar la inercia térmica de un edificio, estabilizar las temperaturas en el interior y reducir la demanda energética. En consecuencia, si utilizáramos estos materiales podríamos tener un parque de edificios más eficientes energéticamente. No obstante, ¿estos materiales son apropiados para usarse en edificios? ¿Se podría generalizar la incorporación de materiales de cambio de fase en edificios con estructuras de hormigón? Este artículo tiene como objetivos hacer una revisión del estado del arte de estos materiales de cambio de fase desde el punto de vista de los profesionales de la construcción, estudiar las aplicaciones en edificios con estructuras de hormigón armado y los puntos clave para estas aplicaciones, extraer conclusiones y recomendaciones útiles para los profesionales del sector que se planteen la utilización de estos materiales.

PALABRAS CLAVE: Materiales de cambio de fase (PCM); Eficiencia energética; Hormigón armado; Estructuras

Copyright: (C) 2014 CSIC. This is an open-access article distributed under the terms of the Creative Commons Attribution-Non Commercial (by-nc) Spain 3.0 License.

\section{INTRODUCTION}

The energy demands of the construction sector are considerable and account for between $20 \%$ and $40 \%$ of the total energy consumption of the most developed countries (1). This fact explains guidelines, such as those of the European Union (2), that contemplate a reduction in the consumption of primary energy of between $32 \%$ and $40 \%$ by the year 2050 . In a similar vein, the incorporation of phase change materials (PCMs) into solutions adopted during construction allows fluctuations of temperature inside 
buildings to be controlled and energy demands to be reduced (3). However, PCMs are not well known and rarely used in the construction sector.

Examples of PCMs are alkanes (organic) and hydrated salts (inorganic). A PCM is a substance: a) whose melting point is within the range of temperatures at which it will be used; b) with a high specific heat; and c) that has a high enthalpy of phase change. As a consequence, when they change from solid to liquid and vice versa, they are capable of storing or releasing, respectively, large quantities of energy. Therefore, PCMs have a high energy storage density in the required range of working temperatures.

Certain PCMs (4-7) melt within the range of comfort temperatures of buildings. In such cases, the properties of these PCMs can be used to store thermal energy and consequently to reduce the energy demands of buildings. Of course, all solids store heat when their temperature increases, in the form of sensible heat, in accordance with their heat capacity. However, this represents a lower energy density than that of suitable PCMs over the small ranges of comfort temperature of buildings. So, for example, in a building with walls of solid concrete, a high thermal mass can only be achieved at thicknesses of $50 \mathrm{~cm}$ or more, and over large temperature ranges (8).

PCMs can be used in active or passive systems of thermal control in buildings (9). The present study only focuses on passive applications. These increase the thermal inertia of buildings and, as a consequence, stabilise the inside temperatures of architectural interiors. This in turn eliminates the peaks in cooling requirements and reduces the need for heating.

Here we study the use of PCMs in reinforced concrete structures. The structure is the building entire set of resistant elements. It is responsible for receiving the actions that affect the construction and transmitting them to the foundations, while meeting strict requirements regarding deformations and maximum stresses. The structure, without including the foundations, accounts for an important part of the environmental impact and of the cost of the building. Its construction results in the emission of between 20\% and $30 \%$ of the $\mathrm{CO}_{2}$ generated in the construction of the entire building in the case of residential blocks (10) and its cost is between $20 \%$ and $40 \%$ of the total cost of the building in the case of school buildings (11). The structure is a promising element for the inclusion of PCMs because, unlike other parts such as the facade, it is usually located inside the building. Consequently, structures containing PCMs would contribute directly to stabilising the interior temperature and they would be protected from outside environmental conditions. Nevertheless, the use of PCMs in the structure of buildings is still a novel idea, as the majority of studies have focused on the incorporation of PCMs into the external enclosure of facades. Reviews that take into account some of the mechanical characteristics of concrete containing
PCMs have only been undertaken in recent years, (12), when the use of PCMs in prefabricated concrete has started to be analysed (13). It is only now that trials of mechanical tests have been used to characterise structural concrete containing PCMs (14).

The aim of this paper is therefore to consider whether the use of PCMs in structural concrete is viable, while reviewing the technical literature concerning the application of PCMs in concrete structures and attempting to provide a functional and structural view of them. To this end, the key points that are introduced into the planning and laying of reinforced concrete structures through the use of PCMs are analysed. Finally, there is a discussion of whether the incorporation of PCMs into structural concrete is feasible, with conclusions and recommendations for the sector.

\section{MATERIAL AND PRODUCTS CONTAINING PCMS}

In this section, first we present a brief recap of the characteristics of PCMs used in reinforced concrete structures and provide references to the considerable literature that reports in-depth studies and classifications of them. Then we turn to products containing PCMs; that is, industrially manufactured and commercially available products that are made from PCMs, some of which can be useful in constructing buildings with enhanced energy performance.

\subsection{PCMs}

PCMs are usually classified following Abhat's 1983 scheme (15) which sorts them according to the type of heat exchange and the change of state they are designed to perform through their composition and application. In the range of temperature changes that we are interested in here, the most common PCMs are the following (7):

a) Inorganic PCMs: hydrated salts and inorganic eutectic systems.

b) Organic PCMs: alkanes, fatty acids and organic mixtures.

It can also be useful to classify PCMs according to their latent heat of fusion and their melting point, as given in the 1997 work by Mehling and Cabeza (16). Their properties are compared in numerous studies (17-20). With regard to the objective of the present study, the most important thermal properties of PCMs are:

a) Organic PCMs have low thermal conductivities: lower densities of storage; that is, a lower capacity to store energy per unit volume. They also undergo large changes in volume during the phase change, although they function via the 
change from solid to liquid, when the variation in volume is less.

b) Inorganic PCMs have a less versatile range of melting points and working temperatures; but they are compatible with the range of temperatures required for construction applications: between $15^{\circ} \mathrm{C}$ and $70^{\circ} \mathrm{C}$. They exhibit a high degree of subcooling; that is, a delay at the start of solidification during which they do not release their latent heat although their temperature drops below their solidification point. In some cases they undergo segregation in their phase change cycles, which can lead to a reduction of their thermal storage efficiency (7).

Another important drawback is the incompatibility of these PCMs with certain construction materials. This is the case, for example, of the corrosion of metals that inorganic PCMs cause; nonetheless, this is minimal in stainless steel, which exhibits low rates of corrosion $\left(8.60 \mathrm{mg} \cdot \mathrm{cm}^{-2} \cdot \mathrm{y}^{-1}\right.$ in low-temperature storage) and this allows for its use in applications such as encapsulation. In contrast, the high rates of corrosion are unacceptable in copper or carbon steel: up to 723.31 and $175.20 \mathrm{mg} \cdot \mathrm{cm}^{-2} \cdot \mathrm{y}^{-1}$, respectively, in salt-water solutions as PCM for low-temperature storage (21). Furthermore, some organic PCMs, such as fatty acid esters, are not stable in alkaline environments; they react with calcium hydroxide and lose their usefulness as PCMs over a short period of time: some six months. Consequently, it is not advisable to use them in contact with binders that contain calcium hydroxide, in contrast to the case of alkanes which are stable in alkaline environments (22).

\subsection{Products containing PCMs}

Due to the drawbacks mentioned above, in many cases PCMs are not used directly. Instead some form of protective technique is adopted, such as encapsulating or stabilising them.

Products containing encapsulated PCMs are classified according to the type of encapsulation, their shape and size, or whether they are embedded in or affixed to the structure. This can be seen in Table 1 $(7,14,23)$, where the encapsulation is divided in micro- and macro-encapsulation. Figure 1 and Figure 2 (24) present different graphic examples of both types of encapsulated materials.

Encapsulating PCMs averts leakage (25) and allows them to be manipulated while they are laid. In addition, mixing the PCM with certain additives and agents can be a way to overcome its deficiencies and thus enhance its essential characteristics: storage capacity, thermal conductivity, congruent melting, stability, etc. Table $2(7,21,26)$ shows some of these improvement strategies that result in increased applicability of the materials, since they guarantee their performance (reliability, reproducibility, etc.).

Micro-encapsulated PCMs are enclosed in microcapsules with a high-molecular-weight polymeric coating (27). The coating must be compatible with the PCM inside and with the material into which it is embedded. This type of encapsulation presents the following additional advantages: improved heat transmission, due to the large surface area per unit volume; and improved stability, because the separation into phase is limited to the microscopic scale. In contrast, macro-encapsulated PCMs are containers of PCM that are commercialised in different formats: panels, capsules, bags, tubes, etc. (9)

Stabilised PCM products do not require encapsulation, since the behaviour of the PCM has been improved; this is the case, for example, with mixtures of alkanes and HPDE (28). Recent studies recommend the use of ester mixtures without encapsulation as PCMs in buildings due to their increased thermal stability over prolonged periods of heating, reduced volatility, decreased environmental impact and improved resistance to fire $(29,30)$. Research is also underway into: form-stable PCMs (FSPCMs), whose volume does not change and which do not require encapsulation (31); and low-melting-point metal PCMs (32), which despite still being at an initial stage of research, present increased conductivity, volumetric stability and prolonged usefulness.

TABLE 1. Types of encapsulation for PCMs used in the building sector and examples of them $(7,14,23)$

\begin{tabular}{|c|c|c|c|c|c|}
\hline \multirow[b]{2}{*}{ Encapsulation } & \multicolumn{2}{|c|}{ Capsules } & \multirow{2}{*}{$\begin{array}{c}\text { PCM } \\
\text { substances }\end{array}$} & \multirow{2}{*}{$\begin{array}{l}\text { Construction } \\
\text { processes }\end{array}$} & \multirow[b]{2}{*}{ Examples } \\
\hline & Shape & Size & & & \\
\hline $\begin{array}{l}\text { Micro-encapsulated } \\
\text { (Fig. 1) }\end{array}$ & $\begin{array}{l}\text { Spherical or } \\
\text { cylindrical }\end{array}$ & $\varnothing<1 \mathrm{~mm}$ & Paraffin & Embedded & $\begin{array}{l}\text { - Granulated, Rubitherm } \\
\text { - Micronal DS } 5008 \text { X } \\
\text { - MPCM-28 wet cake }\end{array}$ \\
\hline $\begin{array}{l}\text { Macro-encapsulated } \\
\text { (Fig. 2) }\end{array}$ & $\begin{array}{l}\text { Depending on } \\
\text { the container }\end{array}$ & $\varnothing>1 \mathrm{~cm}$ & $\begin{array}{l}\text { Organics and } \\
\text { inorganics }\end{array}$ & $\begin{array}{l}\text { Wall and } \\
\text { ceiling linings }\end{array}$ & $\begin{array}{l}\text { - Flat container, Kissmann } \\
\text { - EPS Ltd Module beam } \\
\text { - Bags (Climator, Dörken) } \\
\text { - Celblock } \\
\text { - Aluminum container }\end{array}$ \\
\hline
\end{tabular}




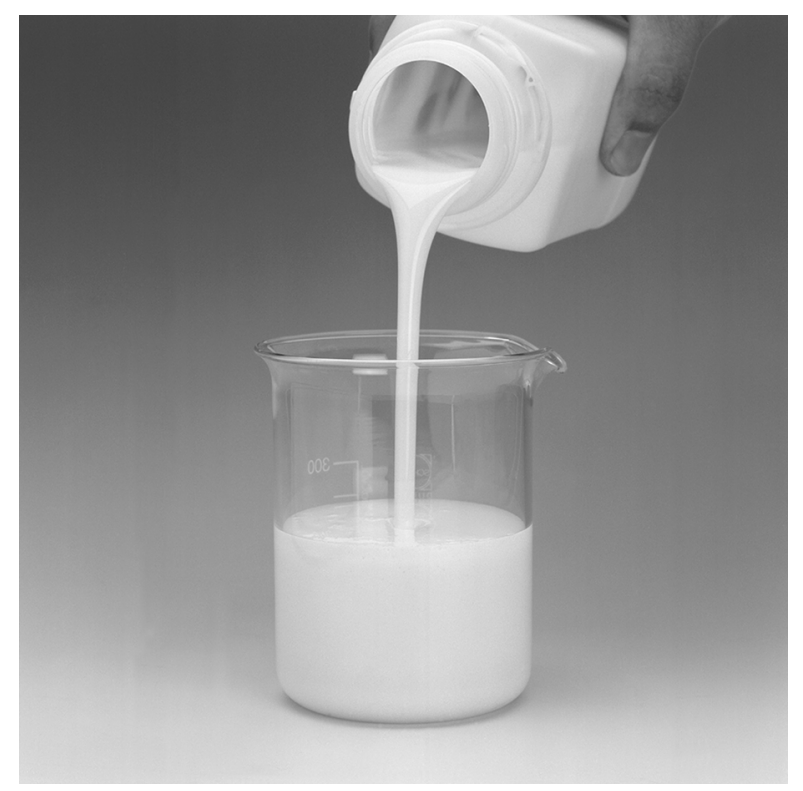

FIGURE 1. BASF Micronal microencapsulated PCM as dispersion, courtesy of BASF.

\section{THE DESIGN AND USE OF REINFORCED CONCRETE STRUCTURES CONTAINING PCMS}

In this paper we study the incorporation of PCM products into different types of structures in reinforced concrete buildings. This includes those built using both concrete poured on site and prefabricated concrete, used in girders, modules, piles or beams; and with one-way or two-way reinforcing (33). Using PCMs in the structures of buildings was first contemplated in the 1970s (34) and 1980s (35), when their use in elements of enclosure was also studied (36) and they were first used to control the temperature of buildings (37).

During the design and development of reinforced concrete structures that incorporate PCM products,

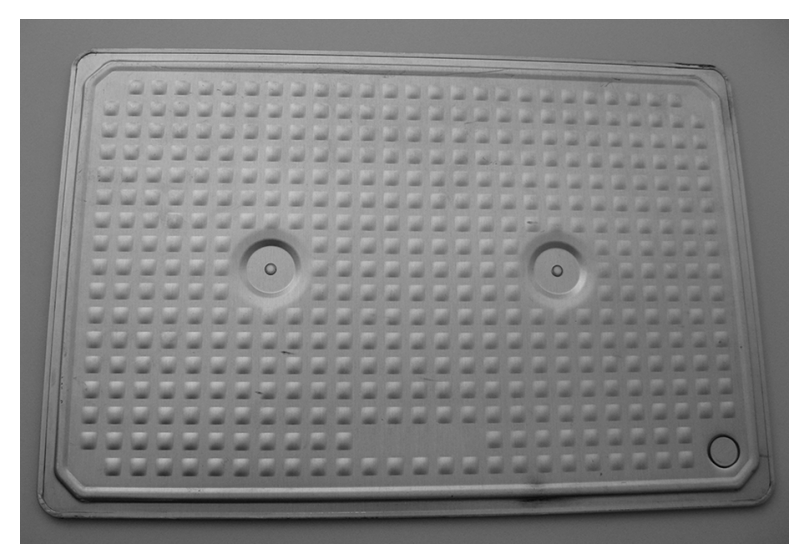

FIGURE 2. CSM Rubitherm Module (24). it is important to take into account the shape in which the products arrive on site and the construction processes used to incorporate the PCM into the building. Table 3 (43) classifies PCMs according to these two parameters and presents both wet construction processes, which involve materials that are made using water-such as concrete-and which can incorporate micro-encapsulated and stabilised PCMs through embedding, immersion and impregnation processes; and dry or mainly dry construction processes in which the PCMs arrive on site as small elements, semi-products or components, and can be incorporated into the building by screwing or nailing them into place, or through the addition of glue, mortar, etc. Semi-products are products that can easily be cut in situ before they are incorporated using dry construction processes; while components leave the factory with their definitive shape and are incorporated as received on site.

All these products could be used in applications involving new construction; while in rehabilitation, small elements and semi-products would be more practical due to their size and their dry mode of use. Impregnation or immersion is a specific method for incorporating PCMs into construction elements that consists of submerging a construction material or element (concrete block, panel, etc.) in a solution of stabilised PCM. This system is laborious and its use should take into account the possibility of leaks (25).

What follows is a review of the main factors that should be taken into account with these materials, from different points of view:

a) Thermal behaviour: The incorporation of PCMs into concrete elements leads to an improvement in thermal performance that is not easy to achieve by increasing the thicknesses of the concrete without PCM, unless it is a considerable increase. As early as the 1980s, it was calculated and corroborated through tests that a construction solution that consisted of an $8.1 \mathrm{~cm}$ Trombe wall containing PCM had greater thermal inertia than the same solution using $40 \mathrm{~cm}$ of concrete (37); or that a $3.5 \mathrm{~cm}$ wall containing PCM could substitute a similar concrete wall of $15 \mathrm{~cm}$ (44). In these pioneer studies, the Trombe walls containing PCMs incorporated calcium chloride hexahydrate $\left(\mathrm{CaCl}_{2} \cdot 6 \mathrm{H}_{2} \mathrm{O}\right)$ with the addition of diatomaceous earth inside tubes embedded in the wall or in cells in the blocks that the wall was built of. In short, it represents an initial PCM efficiency between four and five times greater than that of concrete.

Studies performed this century confirm this relation, since a $16 \mathrm{~cm}$ wall with the addition of an inorganic PCM has a greater storage capacity than a $50 \mathrm{~cm}$ concrete wall (8). Another example is the $1.5 \mathrm{~cm}$-thick Smartboard with Micronal from BASF, with a thermal storage 
TABLE 2. Improvement strategies for PCM encapsulation $(7,21,26)$

\begin{tabular}{ll}
\hline Organic PCM & \multicolumn{1}{c}{ Inorganic PCM } \\
\hline - Additives to improve their heat transfer. & $\begin{array}{l}\text { Mixed with nucleating agents, in thin horizontal layers } \\
\text { and mechanically stirred to avoid segregation and } \\
\text { subcooling. }\end{array}$ \\
$\begin{aligned} & \text { - Encapsulation to reduce their volume changes. } \begin{array}{l}\text { In long term usage, additives to avoid PCM incongruent } \\
\text { fusion, which reduces } 25 \% \text { their storage capacity. }\end{array} \\
&- \text { Encapsulation to improve PCM compatibility with surrounding materials. }\end{aligned}$ \\
\hline
\end{tabular}

TABLE 3. Classification of PCM products depending on their construction processes and the shape in which they arrive to the building site, based on a classification of construction materials (43)

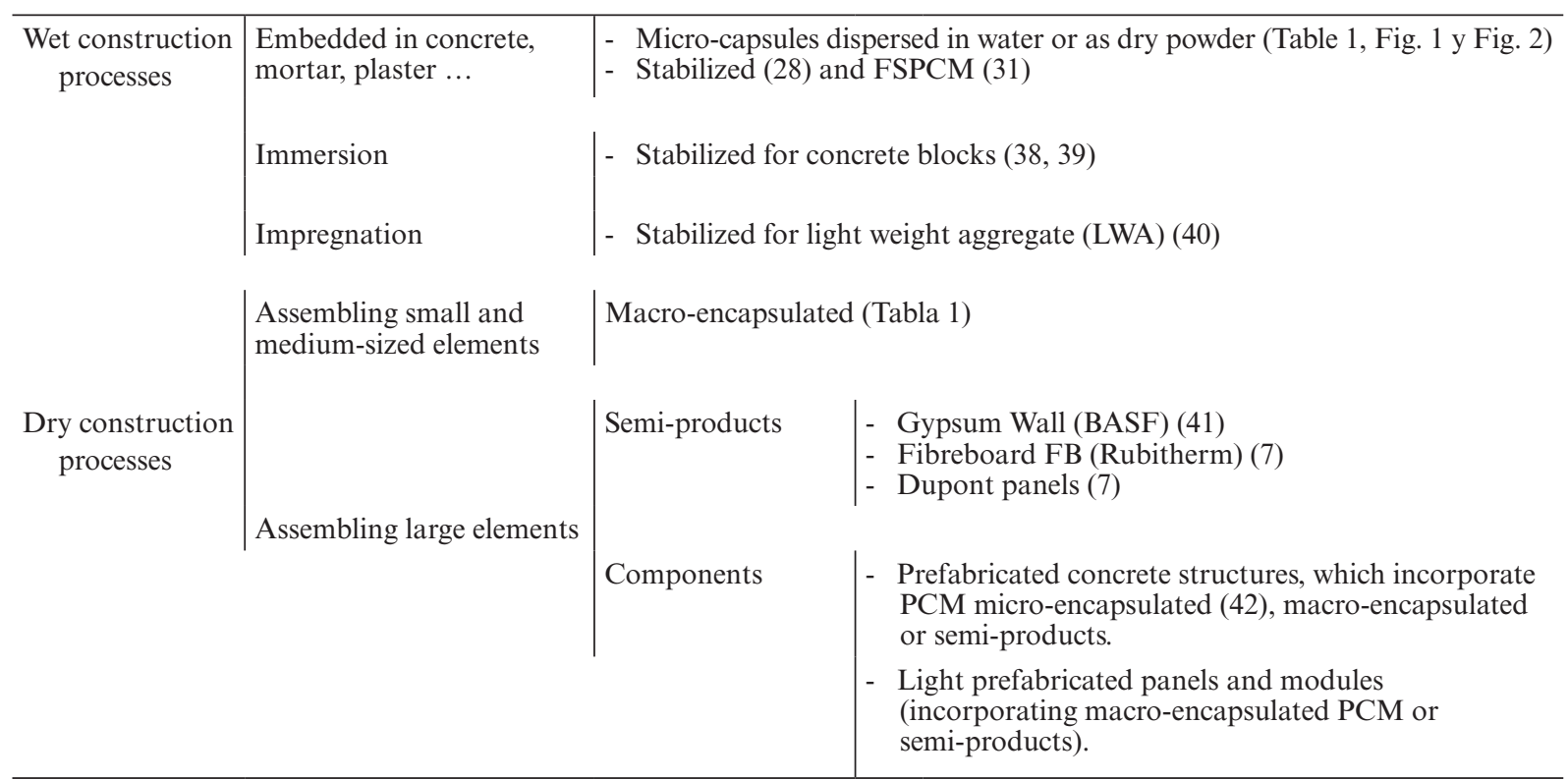

capacity equivalent to $9 \mathrm{~cm}$ of concrete (41). From these experiments, an average equivalence value can be estimated, as an order of magnitude, of 4 times more storage capacity in elements that incorporate PCMs. This is merely a rough value, however, as it varies according to parameters such as the type and the quantity of PCM incorporated; parameters that have not been determined in the majority of the studies.

So, the most promising applications of PCMs in structures improve the thermal performance of the building, increasing its thermal inertia and thereby increasing its capacity to store energy; while reducing the thermal conductivity of the structure. Numerous studies corroborate these improvements that PCM contribute to actual and theoretical buildings $(3,42,45,46)$. There are also studies that calculate the characteristics of the ideal PCM for a specific application (47). These studies corroborate the beneficial thermal behaviour of both micro-encapsulated PCMs embedded in concrete (23) and macroencapsulated PCMs or PCM semi-products lining the structure (26). In any case, it is better to apply the PCM to elements with the maximum exchange surface per unit volume; surface structural elements such as the framework and shear walls. These will produce better results than linear structural elements such as pillars or beams.

b) Cost: At present, the elevated initial cost of PCM products makes it impossible for their use to be the norm within the construction sector. For example, incorporating BASF's Micronal into $1 \%$ and $5 \%$ of the volume represents a price increase of between $35 \%$ and $96 \% 1$. If we consider the cost in the long term, the time required to recover the initial investment, considering the thermal benefits, varies from 10 to 50 years

\footnotetext{
${ }^{1}$ The cost of HA-30/F/20/IIIa reinforced concrete and laying on site for walls with $30 \mathrm{~kg} / \mathrm{m}^{3}$ of B500SD steel reinforcing as given in a construction materials database was considered (48); together with the micro-encapsulated PCM Micronal at $10 € / \mathrm{kg}$, with an apparent density of $300 \mathrm{~kg} / \mathrm{m}^{3}$, in accordance with our purchase of this material from BASF.
} 
depending on the product, the location of the building, etc. (49). Recent studies evaluate lowcost materials used as PCMs: residues, waste from industrial processes, natural oils and the like. To date, five materials with great potential as future PCMs have been identified: two types of alkane, a sub-product of fibres, coconut oil and jojoba oil (50).

c) Environmental impact: PCMs have a greater environmental impact than the majority of conventional construction materials. For example, a factory-ready double-panel polyurethane partition filled with hydrated salts or with alkanes has an impact that is some $8 \%$ or $19 \%$ greater, respectively, than the same partition without the PCM (51). This impact is reduced over the complete life cycle assessment (LCA), given that the impact of production is compensated by reductions in energy demand and $\mathrm{CO}_{2}$ emissions over the useful life of the product. The impact varies according to the type: that of hydrated salts can be compensated over 25 years' use and that of alkanes over 61 years' use (51). In order to optimise entire LCA, it is best to maximise the use of PCMs, maximise the useful life of the building and search for new PCMs with less environmental impact (52). At the end of their useful life, the majority of PCMs can be recycled; organic PCMs are biodegradable and inorganic ones are innocuous.

d) Fire resistance: The different types of PCM react differently to fire: organic PCMs are inflammable and when they burn, the combustion creates toxic gases; while inorganic PCMs are not inflammable. Consequently, semi-products containing embedded PCMs such as alkanes, which are inflammable, require preventative measures to be taken to achieve the response to fire that is required in buildings. Some of the solutions currently in use in plaster panels containing PCMs are: to add a non-inflammable coating to protect them, to apply a fire-resistant treatment to the surface or to use a PCM that when combined with the panel produces a self-extinguishing product (53). Additives are also used to improve the response to fire (7) and recently the use of subproducts such as flame retardants have been studied with promising results (54).

e) Durability: PCMs face problems of durability and of conservation of their properties over time (2.1); these drawbacks have already been considerably reduced in products containing PCMs (2.2). Organic PCMs are highly volatile, age rapidly due to oxidation and undergo changes in their odour; while inorganic PCMs have a problem of stability in their phase changes. However, the durability and stability of PCM products (Fig. 1, Fig. 2) that are encapsulated, stabilised and/or embedded in other materials, are optimised.
Some recent studies have proposed incorporating lightweight aggregate impregnated with stabilised PCM into concrete to minimise the problems associated with the freezing/thawing cycles $(40,55)$ that large concrete surfaces exposed to cold climates, such as face concrete facades, etc. (56), undergo during the useful life.

\section{THE LAYING OF REINFORCED CONCRETE STRUCTURES CONTAINING PCMS}

To build structures that incorporate PCM products, the type of construction process by which the PCM is incorporated into the building, as mentioned above, is a defining factor: 1) wet; or 2) dry.

\subsection{Wet construction processes}

To analyse this type of process, several factors are taken into account, including: composition, the strength of the concrete, the elastic modulus, the quantity of water, its workability, the concreting process, setting and others.

- Composition: When micro-encapsulated or stabilised PCMs are included in the concrete mix, the PCM substitutes a percentage of aggregate or it is used as an additive. For example, tests have been performed in which $5 \%$ to $20 \%$ of the sand is substituted, or the PCM is used as an additive from $5 \%$ to $20 \%$ (14) or as $1 \%, 3 \%$ or $5 \%$ of the total volume (23).

The cement and the PCM product used must be compatible. As mentioned in section 2.1 above, some organic PCMs are not stable in alkaline environments and they react with calcium hydroxide, which leads to a deterioration of the PCM properties. Concrete is an alkaline environment and such PCMs can deteriorate if they are in direct contact with the concrete mixture. If the reaction occurs during the curing process of fresh concrete, the hydration of the cement may be interrupted and this may reduce the strength of the resultant reinforced concrete (57). In order to prevent these reactions, PCM products that are stable or stabilised through encapsulation can be used (section 2.2). In these cases, the most appropriate cement for the proposal is used (58), which in the majority of building structures is Portland CEM I (23) or Type I (14) cement. In contrast, if it is necessary to use an unstable PCM without encapsulation, it is necessary to study ways to reduce the alkalinity of the concrete, for which there is supporting technical literature available (23), and to take into account that certain advantages will be lost, such as the protection that alkalinity offers the reinforcing. 
- Strength of the concrete $\left(\mathrm{f}_{\mathrm{c}}\right)$ : There are concretes containing PCMs that have acceptable strength for structural applications, with the strength depending mainly on the amount of PCM incorporated. Studies and tests have produced concretes with 28-day compressive strengths (fck,28) of $25 \mathrm{~N} / \mathrm{mm}^{2}$ (42); 21,35 and $52 \mathrm{~N} / \mathrm{mm}^{2}$ (23) and from 12.55 to $19.44 \mathrm{~N} / \mathrm{mm}^{2}$ (14), as shown in Table $4(14,23,42)$.

These compressive strengths are between $28 \%$ and $91 \%$ those of the reference concrete and are inversely dependent on the amount of PCM embedded, which substitutes the stronger fine aggregate. Therefore, the incorporation of PCMs into concrete leads to a reduction in the strength of the material, although concrete that is ideal for many structural building applications can be obtained. The flexural strength is also reduced through the incorporation of PCMs, but this is not so significant (14). These strengths depend on the homogeneity of the mix (59) and the resulting granular skeleton which depends on the PCM and the other components of the concrete (23), among other factors.

- Young's modulus (E): The Young's modulus of the concrete is reduced by the incorporation of PCMs. This reduction has not been quantified but it is predicted, given that PCM products are less rigid than the corresponding fine aggregates that they substitute. Studies of concretes made with lower quality aggregates show that they have lower E values $(60,61)$. Although data are not available for the E values of microencapsulated PCMs, the "effective Young's modulus" $\left(\mathrm{E}_{\text {eff }}\right)$ has been calculated using atomic force microscopy (AFM). Table 5 (27) gives values for micro-encapsulated Micronal with particles of different diameters and at different temperatures.
These values of $\mathrm{E}_{\text {eff }}$ are lower than the $\mathrm{E}$ of the sand normally used in the formulation of concrete, which has a size of at least $63 \mu \mathrm{m}$ (62) and it is composed of silica, with grains with $E$ values from 21.6 GPa to $98 \mathrm{GPa}$ (quartz) (63).

- Quantity of water: The incorporation of PCMs leads to an increase in the amount of water required in the concrete mix if the PCM incorporated absorbs water via surface absorption. However, if the PCM is pre-treated (Table 4), there is no variation in the quantity of water needed in the mix, or there is a minimal change, both in the case of introducing micro-encapsulated PCMs and in the incorporation of lightweight aggregate (LWA) impregnated with PCM and water (40), as shown in Table $6(14,23,40)$.

- Workability: The size and shape of the microcapsules (see Table 3) should lead to good workability $(31,40)$, as corroborated in V-funnel, slump-flow and J-ring tests performed on fresh self-compacting concretes (23).

- Concreting process: It is best to add the microencapsulated PCM at the last minute of the mixing process, in order to prevent damage to the micro-capsules (14). Likewise, it is best to embed them in self-compacting concrete and use strong micro-capsules (23).

- Setting: The incorporation of micro-encapsulated or stabilised PCMs into the concrete mix increases the thermal inertia of the concrete, thereby reducing the increase in temperature during the semi-adiabatic concrete curing process, which slows down hydration and thus minimises cracking (54).

- Other points to consider: There are no recommendations for concrete containing embedded PCMs with respect to: the anchorage or coating of the reinforcing; erosion resistance; on-site control and conformity; recyclability; precision; etc.

TABLE 4. Compressive strengths, at 28 days (fck,28), of concretes containing PCM compared to concretes without PCM

\begin{tabular}{llcc}
\hline fck,28 $\left(\mathbf{N} / \mathbf{m m}^{2}\right)$ & \multicolumn{1}{c}{ PCM amount } & $\begin{array}{c}\text { Concrete without } \\
\text { PCM (N/mm }\end{array}$ & Reference \\
\hline 25 & 5\% of weight & - & $(42)$ \\
21 to 52 & 5\% to $1 \%$ of volume respectively & 74 & $(23)$ \\
15,79 to 19,44 & Sand substitution from $20 \%$ to $5 \%$ & 21.44 & $(14)$ \\
12,55 to 16,20 & PCM as an additive from $20 \%$ to $5 \%$ & & \\
\hline
\end{tabular}

TABle 5. Effective Young Modulus ( $\left.\mathrm{E}_{\text {eff }}\right)$ of micro-encapsulated PCM Micronal DS 5001 with different diameters and temperatures

\begin{tabular}{lccc}
\hline Diameter & $\mathbf{E}_{\text {eff }} \mathbf{a} \mathbf{2 5}{ }^{\circ} \mathbf{C}$ & $\mathbf{E}_{\text {eff }} \mathbf{a} \mathbf{4 5}{ }^{\circ} \mathbf{C}$ & Reference \\
\hline $150 \mu \mathrm{m}$ & $4.9 \mathrm{GPa} \pm 2.4 \mathrm{GPa}$ & $7.2 \mathrm{GPa} \pm 4.2 \mathrm{GPa}$ & $(27)$ \\
$6 \mu \mathrm{m}$ & $24.5 \mathrm{MPa} \pm 9.1 \mathrm{MPa}$ & $24.9 \mathrm{MPa} \pm 11.6 \mathrm{MPa}$ & \\
\hline
\end{tabular}


TABLE 6. Variation of the water amount in concretes containing PCM compared to similar concretes without PCM

\begin{tabular}{lclll}
\hline $\begin{array}{l}\text { Amount of water in } \\
\text { concretes containing PCM }\end{array}$ & $\begin{array}{c}\text { Relation water } / \\
\text { cement }\end{array}$ & \multicolumn{1}{c}{ PCM amount } & \multicolumn{1}{c}{$\begin{array}{c}\text { Amount of water in } \\
\text { concretes without PCM }\end{array}$} & Reference \\
\hline $207.4-248.4 \mathrm{dm}^{3} / \mathrm{m}^{3}$ & 0.68 & $1 \%-5 \%$ in volume & $203.2 \mathrm{dm}^{3} / \mathrm{m}^{3}$ & $(23)$ \\
$200 \mathrm{~kg} / \mathrm{m}^{3}$ & 0.57 & $\begin{array}{l}\text { Sand substitution of } 5 \%-20 \% \\
\text { PCM as an additive from } 5 \%-20 \%\end{array}$ & $200 \mathrm{~kg} / \mathrm{m}^{3}$ & $(14)$ \\
$108 \mathrm{~kg} / \mathrm{m}^{3}+\mathrm{LWA}$ & 0.4 & Impregnated LWA & $108 \mathrm{~kg} / \mathrm{m}^{3}+\mathrm{LWA}$ & $(40)$ \\
\hline
\end{tabular}

\subsection{Dry construction processes}

Here we consider the case of PCM products that are incorporated into buildings through dry construction processes. In dry processes, the products are industrially prefabricated using PCMs (23) and they arrive on site ready for assembly. Each one of the different types of product, as classified in Table 3, has different characteristics and a different laying process.

- Macro-encapsulated products, such as aluminium containers, can be affixed to structural surface elements, such as structural walls or reinforced slabs. There are reports of these products making an important contribution to the thermal performance of buildings $(64,65)$. These products should preferably be secured to structural elements using means of affixation that can be dismounted in case of breakdown or at the end of their useful life. It is also advisable to separate these products with joints that allow for their dilatation; and if they are covered by other construction elements, they should also be dismountable. If they are placed over slabs, then they need to be designed as or protected from their use as flooring $(66,67)$.

- PCM semi-products are panels of plasterboard, fibre, etc. that are manufactured containing PCMs and which can be cut to size and affixed to concrete structures $(7,41)$. They are designed for this purpose and the manufacturer's information is available regarding their placement on site (41). If PCM semi-products are used (67), they can be placed in the same way as panels of similar materials that do not contain PCMs (68, $69,41)$ but taking into account the characteristics the PCM confers on them, as explained in this review.

- Components are volumetric elements or modules that include a part of the building, such as a bathroom or a bedroom, and which have been constructed from other PCM products (42). When they are manufactured, it is important whether the materials that constitute them are micro-encapsulated, macro-encapsulated or semi-products, and the information contained in both this section and the preceding one is relevant for them. On-site assembly of these components may be based on similar systems without PCMs (33) taking into account the particularities of the PCM that they contain, as laid out in this review.

If new elements or parts are added to a building whose structure includes PCMs after completion, it is important not to perforate the PCM products as the PCM capsules may be damaged resulting in leakage. This must also be borne in mind during the useful life of the building, since it is important to avoid perforating construction elements that incorporate PCMs. Consequently, all users should be aware of the location, advantages, limitations, etc., of the construction elements that incorporate PCMs, which should be detailed in the plans of the building.

\section{CONCLUSIONS}

The advantages of including PCMs in buildings with concrete structures are numerous. However, it needs to be borne in mind that, as things stand today, the generalised incorporation of phase change products into buildings with reinforced concrete structures is not feasible. Nevertheless, their incorporation should soon be viable, once the following requirements are met:

a) A reduction in the cost and environmental impact of PCM products. The optimisation of their other weak points also favours their incorporation, such as an improvement in the response to fire of organic PCMs and an increase in the strength of micro-encapsulated PCMs.

b) The need for complete technical documentation on the micro-encapsulated and stabilised PCM products that can be incorporated into concrete; the information needs to be accessible to architects and engineers who work with these applications. The mechanical data on encapsulated PCM products and the resultant concrete needs to be available in order to allow the correct development of a project and the design of structures containing PCM. In addition, the thermal data need to be available; those that refer to the PCMs themselves are already available at present. 
c) PCM products require certification for their application in the construction sector.

d) There have to be manuals and user's guides that explain the laying of concrete structures with embedded PCMs, or for them to be affixed to. This should include instructions for mixing, placing, setting, transport, assembly, etc. as well as advice regarding the use and lifecycle of the completed buildings.

e) Rules and guidelines are needed regarding the use of PCMs in the structures of buildings.

f) Awareness and willingness on the part of all those who participate in the construction of this type of building-owners, constructors, engineers, architects, developers, etc. - to introduce PCM products into structures in order to enhance the energetic performance of the buildings. Moreover, projects and construction practices need to maximise the efficiency of PCMs in each application.

\section{ACKNOWLEDGMENTS}

This research was partially funded by the Spanish government (ENE2011-28269-C03-02). The authors would like to acknowledge the support received from the Concrete Technology Research Group of Barcelona Tech (UPC). The authors would also like to thank the Catalan Government for the quality accreditation given to the research group GREA (2009 SGR 534) and the research group DIOPMA (2009 SGR 645).

\section{REFERENCES}

1. Pérez-Lombard, L.; Ortiz, J.; Pout, C. (2008) A review on buildings energy consumption information. Energ. Buildings, 40 [3], 394-398. http://dx.doi.org/10.1016/j.enbuild.2007. 03.007 .

2. European Comission (2011) Communication from the commission to the European Parliament, the Council, the European economic and social Committee and the Committee of the Regions. Energy Roadmap 2050, Com 2011 885/2. http://ec.europa.eu/energy/energy2020/ roadmap/doc/com_2011_8852_en.pdf

3. Tyagi, V.V.; Kaushik, S.C. .; Tyagi, S.K.; Akiyam, T. (2011) Development of phase change materials based microencapsulated technology for buildings: A review. Renew. Sust. Energ. Rev., 15 [2], 1373-1391. http://dx.doi.org/10.1016/j. rser.2010.10.006.

4. Farid, M.M.; Khudhair, A.M.; Razack, S.A.K.; Al-Hallaj, S. (2004) A review on phase change energy storage: materials and applications. Energ. Convers. Manage., 45 [9-10], 15971615. http://dx.doi.org/10.1016/j.enconman.2003.09.015.

5. Rubitherm (2013) PCM's in termal energy storage applications. Available at: http://www.rubitherm.de/english/ pages/04b_glossary_02.htm.

6. Granta Design Limited (2012) CES Selector 2012 software. Cambridge, UK. At: www.Grantadesign.com.

7. Cabeza, L.F.; Castell, A.; Barreneche, C.; de Gracia, A.; Fernández, A.I. (2011) Materials used as PCM in thermal energy storage in buildings: A review. Renew. Sust. Energ. Rev., 15 [3], 1675-1695. http://dx.doi.org/10.1016/j. rser.2010.11.018

8. Al-Karaghouli, A.; Mujaly, L. (2004) Optimum thickness and heat storage capacity of thermal storage wall using different storage materials, Editor Sayigh, A.A.M., World Renewable Energy Congress VIII, Elsevier Ltd.
9. Kenisarin, M.; Mahkamov, K. (2007) Solar energy storage using phase change materials. Renew. Sust. Energ. Rev., 11 [9], 1913-1965. http://dx.doi.org/10.1016/j.rser.2006. 05.005 .

10. Wadel, G. (2009). La sostenibilidad en la construcción industrializada. La construcción modular ligera aplicada a la vivienda (The sustainability of the industrialized architecture. Lightweight modular systems for housing). PhD thesis, UPC, Barcelona, Spain. Spanish digital version at http:// www.tdx.cat/bitstream/handle/10803/6136/TGW01de13. pdf? sequence $=1$.

11. Pons, O. (2009). Arquitectura escolar prefabricada a Catalunya (Prefabricated school buildings in Catalonia). $\mathrm{PhD}$ thesis, Technical University of Catalonia (UPC), Barcelona, Spain. Spanish digital version at http://www. tdx.cat/handle/10803/6133.

12. Ling, T.; Poon, C. (2013) Use of phase change materials for thermal energy storage in concrete: An overview. Constr. Build. Mater., 46, 55-62. http://dx.doi.org/10.1016/j. conbuildmat.2013.04.031.

13. Walter, A.M. (2013) Project - New energy efficient concrete prepared for industrialized production. Phase Change Materials (PCM) in precast concrete. http://www.dti.dk/ projects/project-new-energy-efficient-concrete-preparedfor-industrialized-production/26870

14. Meshgin, P.; Xi, Y. (2012) Effect of Phase-Change Materials on Properties of Concrete. ACI Mater. J., 109 [1], 71-80.

15. Abhat, A. (1983) Low temperature latent heat thermal energy storage: heat storage materials. Sol. Energy, 30, 313-32.

16. Mehling, H.; Cabeza, L.F. (2007) Phase change materials and their basic properties. In: Paksoy H.O., editor. Thermal energy storage for sustainable energy consumption: fundamentals, case studies and design, 257-78, Kluwer Academic Publishers Group.

17. Mehling, H.; Cabeza, L.F. (2008) Heat and cold storage with PCM. An up to date introduction into basics and applications, Springer.

18. Zalba, B.; Marín, J.M.; Cabeza, L.F.; Mehling, H. (2003) Review on thermal energy storage with phase change: materials, heattransferanalysisandapplications. Appl. Therm. Eng., 23 [3], 251-83. http://dx.doi.org/10.1016/S1359-4311 (02)00192-8

19. Wang, X.; Zhang, Y.; Xiao, W.; Zeng, R.; Zhang, Q.; Di, H. (2009) Review on thermal performance of phase change energy storage building envelope. Chinese Sci. Bull., 54, 920-8.

20. Nagano, K.; Mochida, T.; Takeda, S.; Domański, R.; Rebow, M. (2003) Thermal characteristics of manganese (II) nitrate hexahydrate as a phase change material for cooling systems. Appl. Therm. Eng., 23 [2], 229-241. http:// dx.doi.org/10.1016/S1359-4311(02)00161-8.

21. Oró, E.; Miró, L.; Barreneche, C.; Martorell, I.; Farid, M.M.; Cabeza, L.F. (2013) Corrosion of metal and polymer containers for use in PCM cold storage. Appl. Eng., 109, 449-453. http://dx.doi.org/10.1016/j.apenergy.2012.10.049.

22. Hawes, D.W.; Banu, D.; Feldman, D. (1989) Latent heat storage in concrete. Sol. Energ. Mater., 19, 335-348.

23. Hunger, M.; Entrop, A.G.; Mandilaras, I.; Brouwers, H.J.H.; Founti, M. (2009) The behavior of self-compacting concrete containing micro-encapsulated phase change materials. Cem Concr Comp., 31 [10], 731-43. http://dx.doi. org/10.1016/j.cemconcomp.2009.08.002.

24. Rubitherm. CSM module. At: http://www.rubitherm.de/ english/pages/02h_air_heating_systems.htm.

25. Xiao, M.; Feng, B.; Gong, K. (2002) Preparation and performance of shape stabilizes phase change thermal storage materials with high thermal conductivity. Energ. Convers. Manage., 43, 103-8.

26. Oliver, A.; Neila, F.J.; García-Santos, A. (2012) PCM choosing and classification according to their characteristics for their application for thermal energy storage systems. Mater. Construcc., 62 [305], 131-140. http://dx.doi. org $/ 10.3989 / \mathrm{mc} .2012 .58010$.

27. Giro-Paloma, J.; Oncins, G.; Barreneche, C.; Martínez, M.; Fernández, A.I.; Cabeza, L.F. (2012) Physico-chemical and mechanical properties of microencapsulated phase 
change material. Proceedings of the Innostock, The 12th International Conference on Energy Storage.

28. Kuznik, F.; David, D.; Johannes, K.; Roux, J. (2011) A review on phase change materials integrated in building walls. Renew. Sust. Energ. Rev., 15 [1], 379-391. http:/l dx.doi.org/10.1016/j.rser.2010.08.019.

29. Sittisart, P.; Farid, M.M. (2011) Fire retardants for phase change materials. Appl. Energ., 88 [9], 3140-3145. http:// dx.doi.org/10.1016/j.apenergy 2011.02.005.

30. Behzadi, S.; Farid, M.M. (2012) Long term thermal stability of organic PCMs. Proceedings of the Innostock, The $12^{\text {th }}$ International Conference on Energy Storage.

31. Kenisarin, M.; Kenisarina, K.M. (2012) Form-stable phase change materials for thermal energy storage. Renew. Sust. Energ. Rev., 16 [4], 1999-2040. http://dx.doi.org/10.1016/j. rser.2012.01.015.

32. Ge, H.; Li, H.; Mei, S.; Liu, J. (2013) Low melting point liquid metal as a new class of phase change material: An emerging frontier in energy area. Renew. Sust. Energ. Rev., 21, 331-346. http://dx.doi.org/10.1016/j.rser.2013.01.008.

33. Mapston, M.; Westbrook, C. (2010) Prefabrication building units and modern methods of construction MMC. Materials for energy efficiency and thermal comfort in buildings, edited by Hall, M.R., Woodhead publishing series in energy, 14.

34. Barkmann, H.G.; Wessling, F.C. (1975) Use of buildings structural components for thermal storage, Proceedings of the Workshop on Solar Energy Storage Subsystems for the Heating and Cooling of Buildings, Charlottesville, Virginia, USA.

35. Morikama, Y.; Suzuki, H.; Okagawa, F.; Kanki, K. (1985) A development of building elements using PCM. Proceedings of the International Symposiumon Thermal Application of Solar Energy, Hakone, Kana-gawa, Japan.

36. Telkes, M. (1978) Trombe wall with phase change storage material. Proceedings of the $2^{\text {nd }}$ National Passive Solar Conference, Philadelphia, USA

37. Stritih, U. (2003) Heat transfer enhancement in latent heat thermal storage system for buildings. Energ. Buildings, 35 [11], 1097-1104. http://dx.doi.org/10.1016/j. enbuild.2003.07.001.

38. Hawes, D.W. (1991) Latent heat storage in concrete. PhD Thesis Concordia University, Montreal, Quebec, Canada.

39. Hawes, D.W.; Feldman, D. (1992) Absorption of phase change materials in concrete. Sol. Energ. Mater. Sol. Cell., 27 [2], 91-101.

40. Sakulich, A.R.; Bentz, D.P. (2012) Incorporation of phase change materials in cementitious systems via fine lightweight aggregate. Constr. Build. Mater., 35, 483-490. http:// dx.doi.org/10.1016/j.conbuildmat.2012.04.042.

41. BASF. (2013) The Chemical Company. Construction Applications and Systems with Micronal ${ }^{\circledR}$ PCM. Gypsum wall board with Micronal ${ }^{\circledR}$ PCM. At: http://www.micronal. $\mathrm{de} /$ portal/basf/ien/dt.jsp?setCursor=1_290829.

42. Cabeza, L.F.; Castellón, C.; Nogués, M.; Medrano, M.; Leppers, R.; Zubillaga, O. (2007) Use of micro-encapsulated PCM in concrete walls for energy savings. Energ. Buildings, 39 [2], 113-119. http://dx.doi.org/10.1016/j. enbuild.2006.03.030

43. Paricio, I. (1999) La Construcción de la arquitectura. Itec, Barcelona.

44. Zalewski, L.; Joulin, A.; Lassue, S.; Dutil, Y.; Rousse, D. (2012) Experimental study of small-scale solar wall integrating phase change material. Sol. Energ., 86 [1], 208-219. http://dx.doi.org/10.1016/j.solener.2011.09.026.

45. Oliver, A.; Neila, F. J.; García, A. (2011) Incorporación de materiales de cambio de fase en placas de yeso para almacenamiento de energía térmica mediante calor latente: caracterización térmica del material mediante la técnica DSC. Inf. Constr., 63 [522], 61-70. doi:10.3989/ic.09.039.

46. Liu, H.; Awbi, H.B. (2009) Performance of phase change material boards under natural convection. Build. Environ., 44 [9], 1788-93. http://dx.doi.org/10.1016/j. buildenv 2008.12.002

47. Arzamendia, J.P.; Kuznik, F.; Baillis, D.; Yrieix, B. (2012) Optimization of materials for thermal energy storage in building walls. Proceedings of the Innostock, The $12^{\text {th }}$ International Conference on Energy Storage.

48. ITEC(Catalan Institute of Construction Technology). (2010). BEDEC. Online: http://www.itec.cat/noumetabase2.c/ Presentacio.aspx?page $=$ bancbedec. Barcelona.

49. Harland, A.; Mackay, C.; Vale, B. (2010) Phase change materials in architecture SB 10 information and transformation. New Zealand Sustainable Building Conference, Stream 3b - Materials, products and building systems for sustainable, Wellington, New Zealand. Available at: building http://www. branz.co.nz/cms_display.php?sn $=177 \& p g=7050 \& s t=1$.

50. Peñalosa, C.; Lázaro, A.; Delgado, M.; Zalba, B. (2012) Looking for "low cost" Phase Change Materials and their application. Proceedings of the Innostock, The $12^{\text {th }}$ International Conference on Energy Storage.

51. De Gracia, A.; Rincón, L.; Castell, A.; Jiménez, M.; Boer, D.; Medrano, M.; Cabeza, L.F. (2010) Life Cycle Assessment of the inclusion of phase change materials (PCM) in experimental buildings. Energ. Buildings, 42 [9], 1517-1523. http://dx.doi.org/10.1016/j.enbuild.2010.03.022.

52. Castell, A.; Menoufi, K.; de Gracia, A.; Rincón, L.; Boer, D.; Cabeza, L.F. (2013) Life Cycle Assessment of alveolar brick construction system incorporating phase change materials (PCMs). Appl. Eng., 101, 600-608. http://dx.doi. org/10.1016/j.apenergy.2012.06.066.

53. Khudhair, A.M; Farid, M.M. (2004) A review on energy conservation in building applications with thermal storage by latent heat using phase change materials. Energ. Convers. Manage., 45 [2], 263-75. http://dx.doi.org/10.1016/ S0196-8904(03)00131-6.

54. Haurie, L.; Lacasta, A.M.; Realinho, V.; Velasco, J.I. (2012) Improvement of the fire behaviour of PCM in building applications. Proceedings of the Innostock, The 12th International Conference on Energy Storage.

55. Cho, T. (2007) Prediction of cyclic freeze-thaw damage in concrete structures based on response surface method. Constr. Build. Mater., 21 [12], 2031-2040. http://dx.doi. org/10.1016/j.conbuildmat.2007.04.018.

56. Bentz, D.P.; Turpin, R. (2007) Potential applications of phase change materials in concrete technology. Cement Concrete Comp., 29 [7], 527-532. http://dx.doi. org/10.1016/j.cemconcomp.2007.04.007.

57. van Haaren, M. (2011) Application of PCM in concrete. Improvement of the indoor comfort and reducing energy demand. Technische Universiteit Eindhoven. http://alexandria.tue.nl/extra2/afstversl/bwk/749295.pdf

58. UNE-EN 197-1:2000 (2000). Cement-Part 1: Composition, specifications and conformity criteria for common cements.

59. Oliver, A. (2009) Integración de materiales de cambio de fase en placas de yeso reforzadas con fibras de polipropileno aplicación a sistemas de refrigeración y calefacción pasivos para almacenamiento de calor latente en edificios. E.T.S. Arquitectura (UPM). Directores: Garcia, A., Neila, F.J. http://oa.upm.es/2910/1/ALICIA_OLIVER_ RAMIREZ.pdf.

60. Beshr, H.; Almusallam, A.A.; Maslehuddin, M. (2003) Effect of coarse aggregate quality on the mechanical properties of high strength concrete. Constr. Build. Mater., 17 [2], 97-103. http://dx.doi.org/10.1016/S0950-0618(02)00097-1.

61. Al-Harthy, A.S.; Abdel Halim, M.; Taha, R.; Al-Jabri, K.S. (2007) The properties of concrete made with fine dune sand. Constr. Build. Mater., 21 [8], 1803-1808. http:// dx.doi.org/10.1016/j.conbuildmat.2006.05.053.

62. BOE (Boletín Oficial del Estado) (2008) Instrucción de Hormigón Estructural EHE-08. Ministerio de la Presidencia, Madrid.

63. Llorens, J.I., Pons, O., Ruiz, B. (2013) El Terreny i l'estudi geotècnic. Edicions UPC.

64. Castell, A.; Martorell, I.; Medrano, M.; Pérez, G.; Cabeza, L.F. (2010) Experimental study of using PCM in brick constructive solutions for passive cooling. Energ. Buildings, 42 [4], 534-540. http://dx.doi.org/10.1016/j.enbuild.2009.10.022

65. Ostry, M.; Klubal, T.; Charvat, P.; Klimes, L. (2012) Comparison of different latent heat storage techniques integrated in building structures. Proceedings of the Innostock, The $12^{\text {th }}$ International Conference on Energy Storage. 
66. Cerón, I.; Neila, J.; Khayet, M. (2011) Experimental tile with phase change materials (PCM) for building use. Energ. Buildings, 43 [8], 1869-1874. http://dx.doi.org/10.1016/j. enbuild.2011.03.031.

67. Oliver, A.; Neila, F.J.; García, A. (2011) Physical and mechanical characterization of gypsum boards containing phase change materials for latent heat storage. Mater. Construcc. 61 [303], 465-484. http://dx.doi.org/10.3989/ mc.2011.53309.
68. Neila, J.; Acha, C.; Higueras, E.; Bedoya, C. (2008) Phase Change Materials (PCMs) for energy storage in architecture. Use with the Magic Box prototype. Mater. Construcc., 58 [291], 119-126. http://dx.doi.org/10.3989/mc.2008.v58.i291.

69. Kuznik, F.; Virgone, J.; Johannes, K. (2010) Development and validation of a new TRNSYS type for the simulation of external building walls containing PCM. Energ. Buildings, 42 [7], 1004-1009. http://dx.doi.org/10.1016/j. enbuild.2010.01.012. 